\title{
Questioning Public Participation in Social Media Activities in Indonesia
}

\author{
Muria Endah Sokowati \\ Universitas Muhammadiyah Yogyakarta \\ author correspondence: muriaendah@umy.ac.id
}

DOI: https://doi.org/10.18196/jkm.112025

Article Info

Article history:

Received 22 Apr 2019

Revised 11 Oct 2019

Accepted 13 Nov 2019

\section{ABSTRACT}

The growth of using social media in Indonesia since 2009 has enabled the user to contribute to the online discussion by sharing opinions and feelings, or circulating the digital creativities. Social media gives opportunities for users to be content providers. The number of users takes part in the discussion in social media has brought Indonesia as the capital of the social media world. This label attached to Indonesia since some big cities in Indonesia, such as Jakarta, Yogyakarta, and Bandung recorded as the cities whose residents become the most active social media users in the world. This phenomenon leads to the assumption that social media succeeds in creating public participation. However, that claim is still questionable. Based on data from the Association of Internet service providers (APJII), Internet users dominated by people from the middle class, urban, young and well-educated groups. Some blank spots in Indonesia, including the high price of technology and the lack of quality in operating and using technology, become the problems causing the difficulty in implementing public participation. This paper tried to explore the misleading of the assumption that social media activities in Indonesia have created public participation. It also analyzes how the digital divide becomes the barrier to gain public participation.

Keywords: Public; Participatory Culture; Digital Divide; Social Media

\section{ABSTRAK}

Pertumbuhan penggunaan media sosial di Indonesia sejak 2009 telah memungkinkan pengguna untuk berkontribusi dalam diskusi online, berbagi pendapat dan perasaan, atau mendistribusikan kreativitas digital. Media sosial memberi peluang kepada penggunanya untuk menjadi penyedia konten. Banyaknya pengguna yang ikut serta dalam diskusi di media sosial telah menjadikan Indonesia sebagai ibukota dunia media sosial. Label ini melekat pada Indonesia karena beberapa kota besar di Indonesia, seperti Jakarta, Yogyakarta, dan Bandung tercatat sebagai kota yang penduduknya menjadi pengguna media sosial paling aktif di dunia. Fenomena ini mengarah pada asumsi bahwa media sosial berhasil menciptakan partisipasi publik. Namun, hal tersebut menjadi pertanyaan besar, apakah memang demikian? Berdasarkan data dari Asosiasi Penyedia Layanan Internet (APJII), pengguna internet didominasi oleh orang-orang dari kelas menengah, perkotaan, kelompok muda dan berpendidikan baik. Masih banyaknya blank spot di Indonesia, mahalnya harga teknologi, kurangnya kualitas dalam mengoperasikan dan menggunakan teknologi menjadi masalah yang menyebabkan sulitnya mengimplementasikan partisipasi publik. Tulisan ini mencoba mengeksplorasi asumsi yang menyesatkan bahwa kegiatan media sosial di Indonesia telah menciptakan partisipasi publik. Tulisan ini juga menganalisis bagaimana kesenjangan digital menjadi penghalang untuk mendapatkan partisipasi publik.

Keywords: Publik; Partisipasi Budaya; Kesenjangan Digital; Media Sosial 


\section{INTRODUCTION}

Social media is considered as the means for the public to express their voice. Most people use Facebook, Twitter, Path, Line, We Chat, or Instagram to share anything. Social media is identical to web 2.0 as the application of the World Wide Web (www) popularized by Tim O'Reilly in 2005. O'Reilly mentioned the characteristic of web 2.0 as follows:

"...radical decentralization, radical trust, participation instead of publishing, users as contributors, rich user experience, the long tail, the web as platform, control of one's own data, remixing data, collective intelligence, attitude, better software by more users, play, undetermined user behaviour" (In Fuchs, 2014:34)

Since the booming of social media uses in Indonesia in these ten years, some cases indicated that social media has been succeeded in accommodating public participation in social problems. Some cases often mentioned as proof of the success of social media in gaining public involvement.

Coins for Prita in 2009 was one of the histories in the social media activism phenomenon in Indonesia. Prita, the patient of an International hospital located in Tangerang complained about the lousy service of the hospital. She wrote her lousy experience and shared it in the mailing list. This complaint then brought her into imprisonment since the hospital accused her of defaming the hospital's reputation. Prita was considered to violate the ITE (Information and electronic transaction) law. This law, especially in article number 27, was problematic. This article contradicted to freedom of expression on the Internet. The social media user then directed their attention to Prita by spreading Coin for Prita, a campaign to collect coin from the public to pay the fine, so that Prita can be freed from her incarceration. This campaign was a success, and Prita, then, was freed from prison.

Still, in 2009, social media succeeded in voicing the public's objection of an attempt to criminalize the member of the Commission of Corruption Eradication (KPK). The police set Bibit-Chandra-the head of KPK-as suspects in the case of abuse of authority. This case surprised the public. The public used social media, such as Twitter and Facebook to express their protests. Their pressure was successful in influencing the policy to free Bibit-Chandra from the accusation.

\#ShameonyouSBY in 2014 became the symbol of the public critic to the president's course of action during a discussion of the Local Elections Act. Susilo Bambang Yudhoyono, at the end of his tenure as president, made a controversial policy to change the Local Elections Act. The public was disappointed with the ratification of this law through a voting mechanism. This disappointment was expressed by creating \#ShameonyouSBY.

The presidential election in 2014 left a deep impression on the Indonesian public since it was regarded as the best election in the history of elections in Indonesia. The election succeeded in attracting public participation. The active public participation was indicated from the open discussion through various social media, such as the blog, Facebook, Twitter, Path, Kaskus, instant messaging, like Blackberry Messenger, Whatsapp, Line, and WeChat. This phenomenon demonstrated that social media has become the vehicle to deliver public aspiration or mentioned as the media that support democratization. Seeing the enthusiasm of the public to discuss, promote, and watch the process of the election through social media led to the assumption that social media had gained public aspiration and participation. The Internet has provided an opportunity for the public to be actively involved in the political process. Politics was not only for elites and political activist exclusively, but also became the public affairs. Through social networking, citizen journalism, instant messaging, blogs, or various file sharing sites, brought the public to become the information providers. This was progress in a democracy where the public utilized the means to express their voice freely in the political process.

Social media enables its users to participate actively. It empowers users to be contributors. This blurs the border between the producers and consumers so that the term "prosumer" emerged to describe this situation. It means that each social media user can be the source and receiver of the information. This characteristic has changed the dichotomy between source and receiver in conventional media radically.

Walter Benjamin already predicted it in his classical writing "The Work of Art in the Age of Mechanical Reproduction." He stated, "thus, the distinction between author and public is about to lose its basic chapter. The difference becomes merely functional; it may vary from case to case" (2006:28). The function of the sender and receiver still existed, but who runs the function is unclear.

The characteristic of social media has emancipated the public. If the public only passively consumed in the age of mass media, now they play their roles as contributorS and the information providerS. Observing the phenomenon of social media usage in Indonesia brought the author to the 
question, can social media be said to have a potential capacity to empower the public, in this case, Indonesian citizens? Is it true that social media usage in Indonesia represents public participation?

\section{RESULT AND DISCUSSION}

\section{Defining Participatory Culture}

The ability of the web 2.0 to encourage the users to have participation already mentioned by Henry Jenkins when he explains the concept of participatory culture. The focus of participatory culture according to Jenkins's explanation is in the way web 2.0 users are creative since they generate and diffuse user-generated content. He also underlined that the web has become a site of consumer participation. According to Jenkins:

... a culture with relatively low barriers to artistic expression and civic engagement, strong support for creating and sharing one's creations, and some type of informal mentorship whereby what is known by the most experienced is passed along to novices. A participatory culture is also one in which members believe their contributions matter, and feel some degree of social connection with one another.... (Jenkins, 2006:7).

The culture of participatory enabled people to contribute to the web discussion freely when they ready. People can share their creations, support to others, or object to one's opinion. Jenkins also stated that the participatory culture has shifted the literacy's point of view, from individual expression to community involvement (2006:7). To show the focus on community involvement, Jenkins then classified the participatory culture into four forms: affiliations, expressions, collaborative problem solving, and circulations (2006:8). These forms link closely to each other and mutually dependent.

Affiliations mean formal and informal membership in the online community, such as Facebook, Twitter, Path, Instagram, etc., which connect their members through social networks. Expressions refer to the production of new creative forms. Youtube is the best example of the social media platform that enables users to share their video-making. The other example is Pinterest where users can share and circulate their interests and idea and also connect people who have the same interest. Collaborative problem solving is the way the media encourages its users to work together in teams, both formally and informally, to build and develop new knowledge. Wikipedia, online journalism and online gaming are other examples. The last category is circulations that shape the flow of media. Activities such as blogging and podcasting help users to share their activity, voice, feeling, expression and whatever to other users.

These forms explain how social media is the potential to empower users. The participatory culture model, according to Jenkins has included: "the opportunity for peer to peer learning, a changed attitude toward intellectual property, the diversification of cultural expression, the development of skills valued in the modern workplace, and a more empowered conception of citizenship" (2006:3). Jenkins' argument of the phenomenon of social media showed his optimism for this technology. He focused on the strength of the technology: its interactivity, as the main factor, which gives support to the users to empower themselves.

However, Jenkins' concept of participatory culture is problematic actually. His idea seems to simplify the terminology of "participation." Jenkins just simply defined the term "participation" as the public involvement in the web discussion. He ignored the political connotation attached to the term "participation". As a comparison, the concept of participation explained by Stoker will be quoted (1997). Stoker defined the concept of participation to explain the public or community participation related to political participation. According to Stoker, participation means:

....members of the public taking part in any of the processes of formulation, passage, and implementation of public policies (Stoker, 1997).

Stoker's definition emphasized public participation relating to the development of policy, decision-making and its implementation.

To understand how social media activities as the form of public participation, focus on the users' involvement in an online discussion or the users' opportunity to access and posts the digital content is not ample. As part of global Media Corporation, the examination of participation in social media cannot be separated from the economic, politic and social aspects. Christian Fuchs (2011) stated that participatory culture related to participatory democracy. This term has political, economic and cultural dimensions. Fuchs criticized Jenkins' argument of participatory culture that ignored "the questions 
about the ownership of platforms/companies, collective decision-making, profit, class and the distribution of the material benefit.

Based on this concept, the research will focus on the idea of participation that leads to the understanding of democratization. Public participation does not simply refer to public activity in social media. Public empowerment is parallel to the concept of emancipatory society (Habermas, 1989) meaning that people are free from unnecessary domination of anyone's interest, and everybody has equal opportunity to participate in decision making.

Emancipatory society took place in a public sphere, a place where people can come together to discuss and identify societal problems deliberately. The discussion of the people, then, can influence political action. This sphere's condition is characterized as follows: the formation of public opinion; all citizens have access; the freedom of assembly, the freedom of association, the freedom to expression and publication of opinions; and debate over the general rules governing relations.

The characteristics of the sphere that support the emancipatory society seem relevant to Jenkins' concept of participatory culture. There are some overlap keywords, such as: "the formation of public opinion" and "the freedom of expression" with "the low barriers to artistic expression"; "the freedom of assembly and association" with the concept of "affiliation", "the publication of opinions" with the idea of "circulations"; or "the debate over the general rules governing relations" with the idea of "collaboration problem solving". These relevancies do not mean that Jenkins' concept of participatory culture matches Habermas' theory of the public sphere.

In his famous book titled The Structural Transformation of the Public Sphere, Habermas (1991:227-228) explained the freedom of expression and the equal access to speak cannot be found in the public sphere created by bourgeois class. The bourgeois public sphere created the gap between a person who has different formal education and material resources. The inequality also happened since the big companies dominated the public sphere. The domination caused by the political-economic power in Habermas' concept was the lack of Jenkins' argumentation. The reality in the web 2.0 is the reality created by the powerful corporation. The problem of domination should be involved in its analysis.

Using Habermas' concept of the public sphere, it is essential to analyze the case of using social media in Indonesia. Some questions can be addressed, such as "can social media users be deemed as "public"?. It can be stated simply the term "public" has the same meaning as "citizen." In the online world, the term "netizen" or citizen on the net is employed. Can netizen is equalized with the concept of public or citizen? For the second question, to understand whether user activity becomes public participation or not, understanding netizen's online activities is necessary.

\section{Rethinking Public Participation In Social Media Activism}

To answer those questions, we have to look at the profile of Internet users in Indonesia. According to the data from APJII (2014), the penetration of Internet users in Indonesia was still low. It is about $34,9 \%$, meaning from 252,4 millions of Indonesian population, the Internet users are only 88,1 million. The geographic concentration of Internet users was in Java (52 million), followed by Sumatera (18,6 million), Sulawesi (7,3 million), Nusa Tenggara, Maluku and Papua (5,9 million), and Kalimantan (4,2 million). This data showed that most of the Internet activities operated in Java.

The demographic data showed that based on sex, the number of male and female users were almost the same. The female user users were $51 \%$, whereas male users were $49 \%$. Based on ages, $49 \%$ of users were in the age of 18-25, followed by age of $26-35(33,8 \%), 36-45(14,6 \%), 46-55$ $(2,4 \%)$, and 56-65 (0,2\%). From an educational background, most Internet users were well educated. It was $88,8 \%$ of users whose level of education was from senior high school and upward. Based on the profession, Internet users were dominated by employees and entrepreneurs $(55 \%)$, followed by university students $(18 \%)$, housewives $(16 \%)$, and the rest are students and unemployment.

From the APJII research publication in 2012, it was mentioned that Internet users spent more than 1 million per month on living. $39 \%$ of them spent $1-2$ million per month, $33,1 \%$ spent $2-3$ million per month, and $28 \%$ spent more than 3 million per month. This data showed that, as a rule, Internet users are from middle-class families. Based on the data, it can be concluded that Internet users in Indonesia come from middle-class families, young, well educated and from urban areas. Can this profile represent the public? 
The term "public" and "society" can be interchangeable. Korten (in Muluk, 2006) said that society means a group of people who share the same interest. It also refers to a population living together in the same location and interacting with each other. Against that background, it is simply said that the Internet or social media users cannot be identified as public since it is represented only one-third of Indonesian citizens from a certain class of society.

Nevertheless, rather than problematizing whether it is public or not, considering to redefine the term public as the product of representation appears more preferable. Quoting from Coleman and Ross, there is no a priori public that is "captured" or "recorded" by the media. The public is invoked through processes of mediation that are dominated by political, institutional, economic, and cultural forces (Coleman\&Ross, 2010). The assumption that social media activism is the implementation of public participation could mislead if the public is merely defined as the people who live in the same location that is bound with the same interest. Some cases showed that public participation is mentioned as if it is represented by the Indonesian population, but in fact, it is just represented as a particular group of interests.

Cases on the problem of transportation that happened in December 2015 have indicated how there was the wrong conception in using the term "public." On 9th December 2015, the minister of transport, Ignasius Jonan, announced his regulation mentioned in his letter of announcement number UM.3012/1/21/Phb/2015. He prohibited the practice of public transport based on online applications, such as Go-Jek, Go-Box, Grab Bike, Grab Car, Blue Jek, Lady-Jek, etc. His final decision considered that the operation of transportation based on the online application did not comply with the Traffic and Transportation Law number 22/2009 and The Government Regulation of public transportation number 74/2014. The regulation required the public transportation must have legal status and license of providence public transport. All open vehicles based on the online application that operated in Indonesia does not have both license and legal status.

A week after the enforcement of this controversial regulation, president Joko Widodo had to cancel it. He mentioned in his Twitter account that the regulation caused the problem to the citizens. The regulation's cancellation was encouraged by the netizen's objection of the regulation that did not support the needs of the public. The netizen protested this policy by creating hash-tag (\#savegojek), memes, critical discussions, and online petition in social media. They also thought that the government had failed in accommodating the fast growth of technology. This cancellation was identified as the victory of people's voices or the win of the populist economy as stated by Nadiem Makarin, the CEO of Go-Jek, one of the transportation based on an online application company. This statement is misleading since Go-Jek users are only from a certain class.

Who are the Go-Jek users? Since there is no data to describe the profile of the users of Go-Jek available, to identify them is by focusing on the Go-Jek users' must-have properties. Both drivers and passengers must have a smartphone with enough credits for an online connection. The smartphone they have must provide some applications, such as an online map or GPS (Global Positioning System), and the Go-Jek application. For the drivers, they must have their own motorcycles. From these must-have properties, two things can be concluded: first, Go-Jek users are from the middle class since the smartphones they have are not cheap ones. Second, the users' must-have capability in operating technology since the technology supporting Go-Jek operation is not simple. Based on two characteristics identified, it can be said that Go-Jek as online transportation is not for everybody. Nadiem Makarim's claim that the policy's cancellation as the victory of people's voice, or the win of populist economy, seems to exaggerate.

A couple of days after this controversial regulation, there were some accidents caused by a metro mini, other public transportations in Jakarta. Metromini is the typical public transportation in Jakarta since the 1960s. It is famous as cheap public transportation for Jakarta people. For it has operated for years, the metro mini has a low reputation because of the improper service for the passengers and often responsible for some accidents. The last accidents happened in December 2015, the metro mini has caused an accident that made 18 people died. An electric train hit the metro mini since the driver did not stop the engine and broke through the gate. This accident provoked the governor, Basuki Tjahya Purnama, to confiscate 1600 buses with unsuitable conditions. He also intended to stop the operation of the metro mini. The governor's plan brought to the protest of the drivers. They threatened to strike as the reaction of the governor's policy. The drivers' strike became the netizen's mocking in the online discussion.

Detik.com, the popular online news site, conducted a survey on Twitter users to gain their opinion of the driver's strike. The questions were about how important the metro mini for them. From 2.270 
tweets who participated, about $88 \%$ of the users did not care about the driver's strike and assumed that the strike did not have any implication. They even did not care whether the strike would be done forever (Metromini Mogok Massal: Dari 2.270 Tweeps, 88\% Ingin Metromini Mogok Selamanya, 2015). Detik.com published this survey, and the publication explained as if this survey represented all of the elements in society. The title of the publication indicated that the surveys represented all the public's voice. The title was Suara Masyarakat: Kalau Perlu Metromini Mogok Selamanya, Goodbye Metromini (2015) (Public's Voice: If It's Necessary, Metromini can strike forever, Goodbye Metromini). This title was misleading, obviously. Twitter users did not represent the metro mini passengers who came from the lower class of society. The drivers' strike maybe would not affect Twitter users because they were not passengers.

The two cases indicated that what explored online are regularly concluded as the representation of the public aspiration. Based on the Internet user profile, the public online only makes up one-third of the whole population. "Public" in this case means - quoting Coleman and Ross (2010) that already mentioned - the public that was created by the dominating institution, such as Twitter, Facebook, Detik.com, CEO of Go-Jek, and other powerful institution. The interest behind this public creation is to preserve their interest by conditioning their conception of "public" as the real public. Besides the issues in term "public," the term "participation" is also problematic. Is it public participation or just public engagement? Participation, quoting Habermas (1991), requires two conditions: critical public debate and free of domination.

Before discussing the critical public debate, it is necessary to understand what Internet users do while they are online. The users' online activities explored in this diagram:

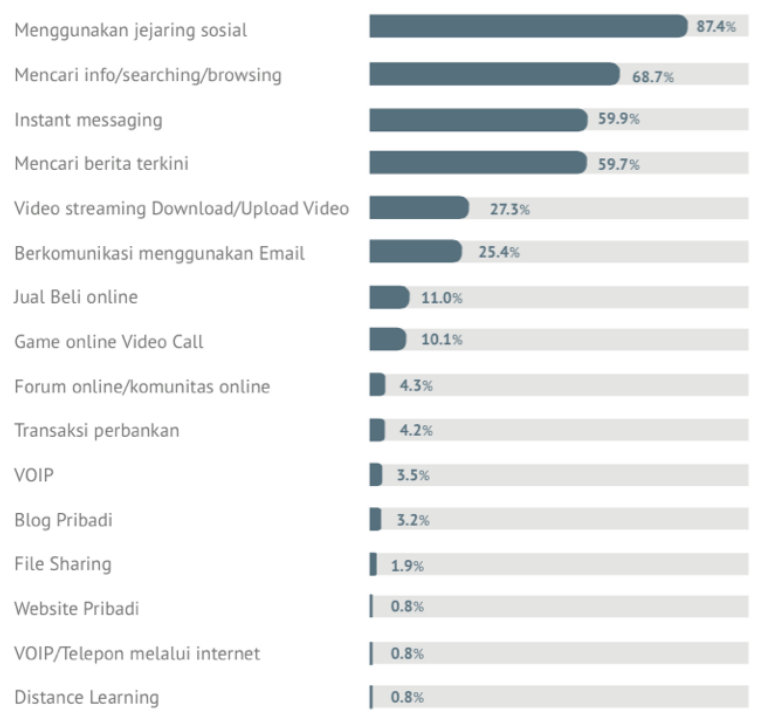

Source: APJII, 2014

Figure 1. Online Activities

Based on the data explored in diagram 1, the five most common users activities were: using social network $(87,4 \%)$, using search engine/browsing $(68,7 \%)$, instant messaging $(59,9 \%)$, updating news $(59,7 \%)$, and video download/upload $(27,3 \%)$. The three top active social media were Facebook, Whatsapp, and Twitter (We are Social \& Iab Singapore's Compendium of Asia-Pacific Digital Statistics, 2015).

While the users spending most of the time using social media, the data from Social Bakers, Media Bistro, Brand24, and Joy Intermedia, in 2013, indicated that social media users paid more attention to content relating to entertainment. According to the data, the most popular Twitter accounts were @ cinema21 (3.420.828), @trans7 (789.630), and @infomaicih (363.691). The other data was about the most popular fan pages on Facebook which reached 7,1-7,6 million likes. The other most popular fan pages were Opera Van Java (Trans 7), Mario Teguh, and Dahsyat (RCTI). The most famous account and fan pages related to entertainment, such as TV programs, celebrities, movies, and 
commercial products. Something that related to the show does not have any relation to the term "participation."

Although most of the users prefer to access entertainment content, some beneficial critical debates can be seen on Facebook or Twitter,.as well as some unproductive public discussions. Hate speech in social media often becomes a problem. For example, the case of Florence happened last year. She was a person who used abusive words in Path against people living in Jogja, and it caused her into the accusation of ITE law violation. Other cases were the black campaign in the presidential election campaign conducted by both the supporter of Jokowi and Prabowo, or the issue pertaining to the hate speech against Syiah, LGBT communities, the victims of 1965's tragedy, or other minority groups.

The other activities are:

1. Self-existence, such as upload photos or selfie, narcissist status; explaining bad feeling sometimes by using improper words;

2. Spreading hoax and unethical content, such as images or videos of the accidents that exploit the victims. Users just receive, read quickly and click (send and spread) without thinking whether the content is valid or not, ethical or no, has good or bad effects;

3. Gathering other users' support of issues by using hash-tag or linking to Change.org. If the issue is important and implicated to the public, it seems unproblematic, but often the petition created is insignificant. For example, a petition to cancel the punishment of Valentino Rossi.

4. Linking to the sites that provide invalid information and sometimes bring to conflict, using inappropriate words or pictures to respond to different opinions, etc.

Public participation should be free of the domination of political or economic interests. It is reasonable to suspect that online media is never free of interest, especially from the economic interest. Change.org is a compelling case. This is a site for an online petition. Anyone can start to create a petition for anything. The site gives access to users to voice and vote and claimed as the social platform for social change. Change.org is described as a democratic medium. As a social platform, this site should be free of any interest. It is somewhat surprising to find the fact that this company is a profit organization, and most people still do not aware of this. For example, Indorelawan.org mentioned that change.org is a non-profit organization. This information is misleading. The information that Change.org is a profit organization is mentioned on the website (www.change.org). When it is a profit organization, it will not be free from economic interest. This case is interesting to be investigated further to reveal the politics behind the practice of online petition, especially in Indonesia.

Based on the explanation and argumentation that already explored, it is too much to claim that social media becomes the vehicle for public participation. It is true that the users can discuss and share anything in the online world, but it is not what the term "participation" explained. By using the words "public" and "participation" improperly, it is understandable if the public participation referring to social media activism in Indonesia is just pseudo-participation. It means that it is not real public participation.

\section{Imagining Public Participation In Digital Divide}

Observing the data of the Internet users profile, there are two critical points to be highlighted. First, there is a digital divide in ages, socio-economic status, geographic location, and education level. It means that the use of Internet-only concentrated in certain ages, socio-economic status, geographic location, and education level (young, middle class, Java and urban, and well-educated). The unevenly distributed infrastructure becomes the causal factor of the gap of the technology. The Internet facility is not available yet in some places in Indonesia. There are some blank spot areas still found. This situation will bring the gap between the haves and the haves not that creates domination.

Second, there is the users' problem in using the technology and information provided. The use of technology cannot support the democratic atmosphere. The users are not ready yet in dealing with the digital culture. While some people still cannot access the Internet, other people who are internet users only could cope with technical skills or how to operate without understanding, evaluating, criticizing the technology, information, and its consequences. This implicates that the users just take advantage of expressing what they want without using it wisely.

It is what Servon (2002) called a digital divide. The government or another policymaker sometimes has simply understood the digital divide as the gap between the haves and the have-nots. 
However, actually, the digital divide is not only about technology ownership. Sevron (2002) explained the digital divide in three dimensions. First, the digital divide is the gap between people who have access to information and communication technology and the others who do not have any access. Second, the digital divide is the gap caused by the problem of technological literacy. Some users do not have the capability of using technology appropriately based on their needs and purposes. Third, the digital divide means the gap of content for users. The content of technology only serves the requirements of certain groups, such as middle class, well-educated, and urban society.

The digital divide initiated the barrier of public participation in social media activism. It brings to the dysfunction of social media as supporting tools for democracy. Public participation only goes on in the emancipation society. According to Habermas (1991), emancipation society refers to a society that has freedom and equality. The society is free from unnecessary domination of any interest, and everybody has equal access to participate in the decision-making process. While the digital divide supports dominations, barely will public participation be achieved.

This condition is also exacerbated by the habit of using the technology of some people. The use of technology is not based on the needs, but the image and status. It relates to the consumerism of society, the condition when people formulate their life goals to have properties to perform their identities (Stern, 2001). The middle-class orientation of material consumption makes sense since they are as the nouveau riche, and do not have any commitment to social justice, human rights or democracy, but the ambition for career and materialism achievement (Robison, 1996:85). The consumption of technology is just the symbol of their class status. So, it is understandable if the hustle discussion going on in social media does not create public participation except users' noise.

\section{CONCLUSION}

Public participation is not implemented yet when describing users' discussion and activism in social media. The users' voice and expression in social media are not public participation. Their voice and expression are not necessarily public participation related to the democratic process. The noise made by the users is unable to encourage people to identify the problem and its solution, or influence the decision-making process, implement and evaluate the policy.

Social media has the potency in emancipating the public. Unfortunately, the problem of access and perspective of users in using technology become a barrier to the creation of public participation in digital in the online world. Some scholars and analysts often simply describe that social media activities lead to public involvement could mislead. It needs to be criticized. This becomes our challenge as a scholar in the media and communication studies in Indonesia to improve the study of social media and digital culture in the critical perspective to reveal the practice of power relations behind it.

So far the study in these areas only celebrated this phenomenon or debating whether it is meaningful or not. Christian Fuchs (2014) already stated by, as follows:

"Contributions to discussions of Internet, social media and the public sphere often tend to stress new technologies' transformative power."

It is the time to enrich the studies with a variety of perspectives, and the political economy approach is one of the recommendations.

\section{REFERENCE}

Benjamin, Walter. (2006). The Work of Art in the Age of Mechanical Reproduction. Dalam Durham, Menakshi Gigi and Kellner, Douglas M. Media and Cultural Studies: Key Works. Australia: Blackwell Publishing

Coleman, Stephen dan Karen Ross, (2010). The Media and The Public. United Kingdom: WileyBlackwell

Digital, Social, and Mobile in APAC 2015. (2015). Singapore: We are Social \& Iab Singapore's Compendium of Asia-Pacific Digital Statistics

Fuhs, Christian. (2011). Against Henry Jenkins. Remarks on Henry Jenkins' ICA Talk "Spreadable Media", from http://fuchs.uti.at/570/, accessed on January 5, 2016

Fuhs, Christian. (2014). Social Media: A Critical Introduction. London and California: Sage 
Habermas, Jürgen (1991). The Structural Transformation of the Public Sphere: An Inquiry into a category of Bourgeois Society. Cambridge, Mass.: MIT Press, 1991

Jenkins, Henry et al. (2006). Confronting the challenges of participatory culture. Chicago, IL: MacArthur Foundation

Metromini Mogok Massal: Dari 2.270 Tweeps, 88\% Ingin Metromini Mogok Selamanya. (2015, 21 Desember). Detikcom. http://news.detik.com/berita/3101382/dari-2270-tweeps-88-inginmetromini-mogok-selamanya, accessed on Januariy2, 2016

Muluk, Khairul. (2006). Desentralisasi dan Pemerintahan Daerah. Jakarta: Bayumedia

Profil Pengguna Internet Indonesia. (2014). Jakarta: APJII dan Puskakom 2014

Robison, Richard. (1996). The Middle Class and Bourgeisse in Indonesia. In Robison, Richard and Goodman, David GS. The New Rich in Asia: Mobile Phones, McDonalds and Middle Class Revolution (h. 79-104). London and New York: Routledge

Servon, Lisa J. (2002). Bridging the Digital Divide: Technology, Community, and Public Policy. UK dan USA: Blackwell Publishing

Stearn, Peter N. (2001). Consumerism in World History: The Global Transformation of Desire. New York: Routledge

Stoker, G. (1997). Local Political Participation. Dalam Hambleton, R et al, New Perspectives on Local Governance: Reviewing the Research Evidence, York: Joseph Rowntree Foundation

Suara Masyarakat: Kalau Perlu Metromini Mogok Selamanya, Goodbye Metromini, (2015, 21 Desember). Detikcom. http://news.detik.com/berita/3101116/suara-masyarakat-kalau-perlumetromini-mogok-selamanya-goodbye-metromini, Accessed on January 2, 2016 